University of Louisville

ThinkIR: The University of Louisville's Institutional Repository

Electronic Theses and Dissertations

1937

\title{
Franco-American relations 1914-1917 as mirrored by the Excelsior newspaper.
}

Sherley Chapman Jenkins

University of Louisville

Follow this and additional works at: https://ir.library.louisville.edu/etd

Part of the Diplomatic History Commons, European History Commons, and the United States History Commons

\section{Recommended Citation}

Jenkins, Sherley Chapman, "Franco-American relations 1914-1917 as mirrored by the Excelsior newspaper." (1937). Electronic Theses and Dissertations. Paper 1809.

https://doi.org/10.18297/etd/1809

This Master's Thesis is brought to you for free and open access by ThinkIR: The University of Louisville's Institutional Repository. It has been accepted for inclusion in Electronic Theses and Dissertations by an authorized administrator of ThinkIR: The University of Louisville's Institutional Repository. This title appears here courtesy of the author, who has retained all other copyrights. For more information, please contact thinkir@louisville.edu. 


\title{
UNI VERSITY OF LOUISVI LIE
}

FRANCO-AlERICAN REIATIONS 1914-1917.

AS MIRRORED BY THE EXCELSIOR NEWSPAPER

\author{
A Dissertation \\ Submitted to the Faculty \\ Of the Graduate School of the University of Louisville \\ In Partial Fulfillment of the \\ Requirements for the Degree \\ Of liaster of Arts
}

Department of History

By

Sherley Chapman Jenkins 
Name Sherley Chapman Jenkins

Title Franco-American Relations 1914-1917 as

Mirrored by the Excelsior Newspaper

Director Dr. James Morgan Read

Approved by:

Director

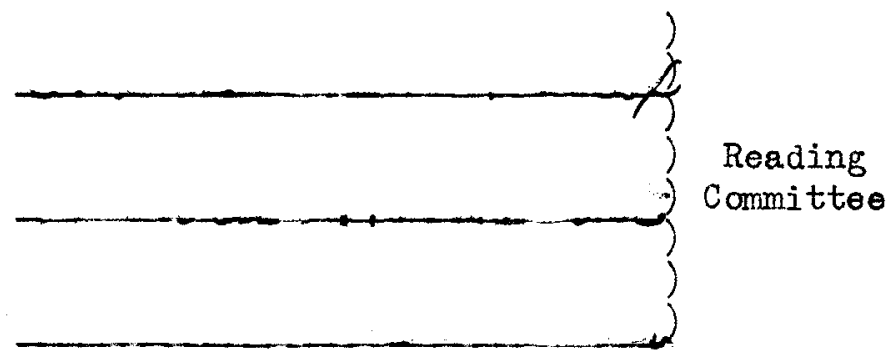

Representative of the Finglish Department.

Date may 31,1937.. 
Table of Contents

42541 
Contents

Page

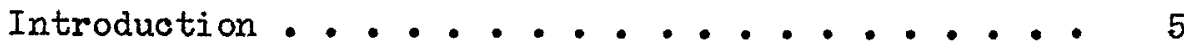

Chapter I. American Neutrality

September 4 to September 28, 1914 . . 9

Chapter II. The Iusitania

May 8 to June 5, 1915 . . . . . 17

Chapter III. The Sussex

Narch 26 to May 12, $1916 \ldots 31$

Chapter IV. The Presidential Election and the Miexican Conflict

June 1 to July 1, 1916 . . . . . 48

Chapter $\nabla$. President Wilson's Offer of Mediation

December 23 to December 31, 1916 . . 54

Chapter VI. The Eve of American Intervention

February 15 to April 7, 1917 ... 61

Conclusion . . . . . . . . 70

Bibliography ..... . . . . . . . 74 
Franco-American Relations

1914-1917 as Mirrored by the

Excelsior Newspaper 
INTRODUCTI OA 
Introduction

The object of this thesis is to present the attitude maintained by France toward the United States during the period of American neutrality in the Great War. Historical documents, books and treatises by authors of varying nationality, private letters and papers of diplomatists and statesmen active at the time, all converge on one belief. That one belief is that France did all in her power to draw the United States into the European conflict, by use of propaganda, by way of entangling financial alliances, by way of contrasting the allied blockade with the German submarine campaign and by devious other methods.

By using the daily publications of the Excelsior newspaper as a reflector for Franco-American relations, the attempt is made here to offer a valid sample of the prevailing French opinions on the subject from 1914 to 1917. In order to acquaint the reader most proficiently with the relations existing between the two countries, the text brings up for consideration main phases in French and American attitudes centering about certain major episodes of the war.

The duty of a newspaper is supposedly to print material reflective of the current of public opinion. E. Malcolm Carroll in his French Public Opinion and Foreign Affairs 1870-1914, says of public opinion: "In its common use it refers to the composite reactions of the general public, but as a rule the only tangible evidence of these 
tendencies is to be found in the opinions of the more influential leaders." 1 Thus in working with a newspaper it is necessary first to examine the character of the paper, its political leanings and the group of people it represents.

The Excelsior is a Paris daily omed and operated by Le Petit Parisien and published in the morning. It was founded in 1910, with $\mathrm{H}$. deWeindel as Editor-In-Chief, and has now attained a circulation of over 325,000 . Its copious illustrations, its tyle of headlines and make-up, and its appeal to conventional bourgeois families, women and youths especially, make it resemble the American daily. "A note-worthy characteristic is the absence of editorial comment or signed articles with a political bias, the paper being more impersonel in tone than any other in France." $\underline{2}$

Hayes tells us that Le Petit Parisien, operator of the Excelsior, has not only the largest circulation of all French newspapers, but the largest in the world. $\underline{3}$ The aim of the paper is impersonality and complete objectivity. It is popular among the masses principally because of its many comic cartoons and the fact that it plays up the crime element. Politically it has maintained a middle course; emphasis is given to utterances of politicians actually in power, important speeches of the opposition, whether left or right, being relegated to inside pages.

1. Carroll, E. Malcolm, French Public Opinion and Foreign Affairs, 1870-1914, p. 4 .

2. Hayes, C. J.H. France, a Nation of Patriots, p. 435 .

3. Ibid., p. 448 . 
Thus wo see that the Excelsior and its foster peper, Le Petit Parisien are conservative. It is common belief that all newspapers are prone to distort facts. With this view in mind, the author will endeavor to present various important phases of the World War as published by the Excelsior, shading or coloring them by as close an approximation to accuracy and truth as can be obtained from a compilation of various sources and authors. Truth is one thing; interpretation another. Facts sometimes in their interpretation can be made to seem fairy tales. Conscious of these things, let us turn to the Excelsior. 
CHAPTER I

AMERICAN NEUTRALITY

SEPTEMBER 4 to SEPTEMBER 28, 1914 
CHAPTER I

EARIY AMERICAN NEUTRALITY

SEPTEMBER 4 to SEPTEMBER 28,1914

The Austrian heir apparent to the throne was assassinated at Sarajevo on June 28, 1914. The Russian army mobilized on July 30. Two days later, August 1, the catastrophe broke forth with the German declaration of war. France and the whole continent were too busy to give a thought to America in these early days. America herself wa almost too dazed to grasp the significance of the outburst.

As the month of August passed and 1914 rolled into September, it is interesting and surprising to notice that French newspapers were beginning to discuss the American attitude. Numerous questions seemed to be rearing their heads. What would be America's reaction? Would she remain neutral, or would she too plunge into the engulfing volcano? Supposing she should plunge, which side would appear less ongulfing to her?

During the entire month of September, the Excelsior expresses a god-like reverence for the United States, her opinions and her sense of fustice and faimess. We find the paper publishing articles on the Amerioan reception of German vandalism, interviews, quoting the opinions of various eminent American citizens on the question of neutrality and warnings from President Wilson to German diplomats.

As early as the first week of September, we find an article quoting Mr. Winston Churchill on American neutrality - William G. 
Shepherd, a representative of the United Press of the United States, having obtained an interviow with Mr. Churchill, asked the latter if outside of moral consequences, the United States had direct interests in the result of the war. The Excelsior publishes Mr. Churchill's response:

You are the only judges. You will not ask me to speak of your interests. If England in the present war, or in another which would surely follow if this were not conclusive, were reduced to the position of a small country like Holland, then as far away as your country may be (the other side of the cean) the burden would fall on your shoulders. I don't wish to say that Germany would absolutely attack you, or if you were attacked you would have to learn the consequences. You know. But the Monroe Doctrine extends to South America as well as to North America, and is it probable that victorious German militarism which would then have irreparably annihilated France, conquered Belgium and broken forever the power of England, would accept the permanent position of giving up all hope of expansion and development which South America alone can offer? 1

Early in the month we find French propaganda coming to the front. Confirmation for the claims of C. Hartley Grattan, that French propaganda played up French culture and damned German vandalism $\underline{2}$ is found in the daily's publication of September 6 which reflects the reception vandalism gains in the United States. The Excelsior tells us that American newspapers continue to judge with veracity the procedures of German warfare. The paper cites as examples two cartoons published in various papers of New York:

The Herald has published a sketch showing a bamb from a zeppelin on a mother and her child with this quotation Ceux-ci d'abord.

1. The Exoelsior, September 4, 1914, p. 6, col. 2 .

2. Grattan C. Hartley, Why We Fought, pp. 74-80. 
A sketch from the Tribune of New York shows the German giant treading under foot the city of Louvain. It is entitled The Return of the Goth. 1

Again some days later, September 24, the Excelsior refers to the American reaction to German vandalism by saying that indignation is general in the United States where the newspapers are publishing articles on the destruction of the Cathedral of Rheims. Here it is interesting to note how the American papers are quoted in their use of French catchwords such as "Huns" and "Goths":

The Tribune says:

The destruction of this beautiful monument of the middle ages is an act of vandalism which lowers the German military methods to the rank of those of the Goths and Huns, and the crime of having destroyed it has been accomplished by a nation who pretends that its mission is to impose its civilization upon the rest of the world.

The World says:

Prussian militarism has outdone the records of vandalism for centuries. Since the destruction of the Parthenon, the world has not known such an exploit. $\underline{2}$

The first allusion to atrocity propaganda is noted September 9, when the Excelsior publishes a picture of the Belgian Delegation which is going to the United States to make known to "that great American Republic, the acts of barbarism of which the soldiers of William II are guilty". $\underline{3}$

The visit paid by this Belgian Delegation is elaborated and discussed by Ray Stannard Baker in his Woodrow Wilson - Life and Letters:

$$
\begin{aligned}
& \text { 1. The Excelsior, September 6, 1914, p. 4, col. } 1 \text {. } \\
& \text { 2. Ibid., September 24, 1914, p. 7, col. } 1 \text {. } \\
& \text { 3. Ibid., September 9, 1914, p. 8, col. 1-3. }
\end{aligned}
$$


The Belgians arrived at the White House on the afternoon of September 16th, a distinguished group, accompanied by Secretary Bryan and Secretary McAdoo. Their spokesman, Henry Cartou de Wiart, made a moving appeal:

Peaceful inhabitants were massacred, defenseless women and children were outraged, open and undefended towns were destroyed, historical and religious monuments were reduced to dust and the famous Library of the University of Louvain was given to the flames. 1

An example of how the Germans tried to counteract French propaganda is evident when on September 7 the Kaiser protested to President Wilson that the allies were using dum dum bullets. "This kind of warfare", he worte, "has become one of the most barbarous knowm in history". 2 Three days later President Poincar of France charged that Germany herself was using dum dum bullets and was only trying to confuse the issue. The telegram from Poincare is published in the Excelsior September 13. An important point to be observed is that for the first time comes publication of official notes:

To His Excellency, Mr. Woodrow Wilson, President of the Republic of the United States at Washington, Monsieur le President,

I am inforned that the German government has sought to obtain the good faith of your Excellency in alleging that dum-dum bullets were being made in the factories of the French state and being used by our soldiers. This calamity is only an audacious attempt at the interversion of roles; Germany has since the beginning of the war used dum-dum bullets, and has committed cantinual violations of the rights of the people. The eighteenth of August, and several times since then, we have been forced to call the attention of Your Excellency to this, according to the Signatory Powers of the Hague Convention.

Germany knows of our protests and seeks today to change

1. Baker, Ray Stannard, Woodrow Wilson - Life and Letters, pp. 160-161.

2. Foreign Relations of the United States, Supplement, 1914, 
it, and to threaten on the pretext of pouring on us again these acts of barbarism.

In the name of abused right and outraged civilization, I send to Your Excellency my sincere and indignant protestation.

$$
\text { Raymond Poincard } \stackrel{1}{=}
$$

The response of President inils on to the Kaiser's note is printod September 19. This is a dispatch telegraphed from Washington to the Exchange Telegraph at London, and telegraphed in turn to Paris; it informs us that President Wilson has replied to the protestation of the Kaiser concerning the pretended use of dum-dum bullets by the French by saying "that the United States Government cannot intervene, and has for the moment nothing more to say". $\underline{2}$

The Excelsior proves how highly it esteems American thought when it takes the trouble of printing September 26, an article published in Washington the preceding day, in wich it is learned that the New York World has asked sixty superior officers of the American Army their opinion on the duration and the is sue of the European war. The majority of the officers consulted estimate that "the war will last one year, and that Germany will be defeated after being forced to fight on her territory". 3

A peculiar incident, little observed in histories of American neutrality, is magnified by the French into a major diplomatic episode on September 26, when the Excelsior publishes President Wilson's warning to German diplomats. This furnishes an interesting insight into Wil-

1. The Excelsior, September 13, 1914, p. 4, col. 1.

2. Ibid., September 19, 1914, p. 3, col. 2 .

3. Ibid., September 26, 1914, p. 2, col. 2. 
son's neutrality, barely two months after the outbreak of war:

Published in New York, September 24:

Baron Von Schoen, new secretary of the German Finbassy at Washington, having said that after an interview that there existed in Japan a very pronounced antiAmerican feeling, was answered by President wilson's saying that if this interview were exact, he would demand the recall of Von Schoen.

This threat is considered a warning to all German diplomats, whose efforts to influence American opinion will not be tolerated. 1

Two days later, the Excelsior's hopes soar high when another telogram from Washington is received via London:

The recall of $A$. Rusten Bey, Ambassador of Turkey at Washington will probably be followed by that of Count Von Bernstorff, Ambassador from Germany, and that of Baron Von Schoen, new secretary of the German Embassy. 2

The Courier-Journal of Louisville, Kentucky, corroborates these statements in an article published September 25. It seems that A. Rusten Bey, in an interview, compared lynchings in the United States and "water cures" in the Philippines to acts which the Turkish people had committed in rigorous uprisings. The Turkish Ambassador was given an opportunity to withdraw his remarks, but he informed President Wilson that he did not care to change his views, and would leave the United States soon of his own initiative on leave of absence. No mention is made of the status of Count Von Bernstorff, but with regard to Baron Von Schoen, the Courier says that he called on Secretary Lansing and personally repudiated the interview in which he was repre-

$$
\begin{aligned}
& \text { 1. The Excelsior, September 26, 1914, p. 2, col. } 2 . \\
& \text { 2. Ibid., } \\
& \text { September 28, 1914, p. 3, col. 1. }
\end{aligned}
$$


sented as saying that the Japanese hated the American people, and that war between the two countries was inevitable. The explanation of the German gentleman was accepted by Secretary Lansing:

The deduction which official Washington has drawn from these occurrences is that President Wilson looks with emphatic disfavor on the circulation of propaganda by the diplomatic representatives of any of the belligerents or governments, if that propaganda is calculated to play upon the patriotism or feelings of the American people in a way that might involve the neutrality of the Unitod States. 1

The most that is actually expressed by the Excelsior this early in the war is hope - hope that either the United States will be sympathetic toward the Entente in her policy of neutrality or that if this policy proves deficient in durability and efficiency, she will come to the assistance of the Allies in their so-called struggle for existence.

1. The Courier-Journal, September 25, 1914, p. 1, col. 6 . 
CHAPTER II

THE LUSITANIA

MAY 8 to JUNE $5, \underline{5} 1915$ 
CHAPTER II

THE LUSITANIA

MAY 8 to JUNE $\underline{5}, \underline{1915}$

May 1, 1915, was a day of tragedy in the affairs of the world. In the morning newspapers appeared the ominous warning of the German embassy to American passengers against crossing the war zone - in ships of Great Britain or her allies. It read:

\section{Notice!}

Trevellors intending to embark on the Atlantic voyage are reminded that a state of war exists between Germany and her allies, and Great Britain and her allies; that the zone of war includes the waters adjacent to the British Isles; that in accordance with formal notice given by the Imperial German Govermment, vessels flying the flag of Great Britain or of any of her allies, are liable to destruction in those waters and that travellors sailing in the war zone on ships of Great Britain or her allies do so at their om risk.

Imperial German Embassy, Washington, D. C. April 22, 1915. 1

On this historic first of May, the great ship Lusitania eased out of her berth and began her last tragio voyage to Europe. The passengers aboard her refused to credit the situation as extremely serious, and commented lightly on the warning - it was just German bluff and swagger. Six days later, May 7, shortly after two $0^{7} \mathrm{clook}$ in the aftermoon, the Lusitania was torpedoed by a German submarine off the Irish coast. There had been 1959 souls on board - 1257 passengers and 702 members of the crew - of whom 1198 were lost. Of the 159 American passengers, 124 perished.

1. New York Sun, May 1, 1915. 
The day the news of the disaster is received, the Excelsior's attitude is reserved; however, with each day, we see the indignation of the paper mounting, and the realization dawning that the fate of this ship may well determine the course of American diplomacy.

In printing the announcement of the torpedoing of the Lusitania the Excelsior comments:

It is recal led that last week a dispatch from New York announced that the German Ambassador had published in the nowspapers a warning to all passengers traveling on allied ships. 1

The following day, the Excelsior carries an article published in New York Nay 8 by the New York Tribune. The column reads that Mr. Wilson will not hasten to do anything until he is assured of firm aid by the citizens of all parties. To quote the President:

In the presence of this national tragedy, we can have only one thought, only one duty, and only one resolution; the nation which remembers the Maine, the American ship whose mysterious destruction led to the Spanish-American war, will not forget the victims of the Lusitania.

The same day on the opposite page is found a glaring headline, "Will grave complications result between the United States and Germany?"

1. The Excelsior, May 8, 1915, p. 4, col. 3 . Gratten emphasizes this detail: "April 22, 1915, a notice was written by Von Bernstorff at Washington, emphasizing the warning of February 4 to all neutrals. By fatality it appeared May 1, the day the Lusitania left Now York. England took it to mean a specific warning to the Lusitania." C. Hartiey Grattan, op. cit., p. 291.

2. Ibid., May 9, 1915, p. 4, col.3. 
With a glance cast at Italy, the Excelsior says that in Rome, Nelson Page, United States Ambassador to Italy, reserves judgment on the attitude of the United States on the Lusitania, until the German guilt is established. If this fact is proved, it will produce serious repercussions in America, and grave complications will develop, according to $\mathrm{Mr}$. Page.

On the same date, we find an article with the heading "The Crime of the Lusitania" which includes fervent opinions extracted from variout dailies. One story tells of an American in London who exclaimed that if the United States did not declare war, he would no longer be an American citizen. Another speaks of the violent indignation aroused in America by the brutal procedures of the German submarine. A third describes the reaction of Theodore Roosevelt to the disaster how he goes on the war path and cries for vengeance.

We see a very interesting commentary on Niay 10, signed General $X$. The General urges participation and co-operation on the part of the United States in no uncertain terms.

The assassination of the passengers of the Lusitania is not an act of war; it is a common crime, a massacre. We wish and hope that the United States will seize the occasion which is offered to them, and will contribute thus to give Europe the definitive peace which they desire themselves and which will put an end to this terrible drama. I

Side by side with this opinionatory statement is written in large letters, "Dr. Dernburg Justifies the Crime of the Lusitania" • Dr.

1. The Excelsior, May 9, 1915, p. 2, col. 1. 
Berhard Dernburg, a former colonial secretary, was rushed to Washington along with Count Von Bernstorff at the beginning of the war - his mission being to organize German propaganda and to enlighten the American Government and the people on the German standpoint. 1 The article says that Dernburg arriving at Cleveland, supposedly to promulgate peace, declared the loss of the Lusitania justified since Germany had given fair warning, and that it was unreasonable to think the boat should not be sunk just because Americans were aboard. "The Transylvania", he said, "which left New York May 7, also runs the same risk" 2

On May 11, a dispatch from Washington, very important to the allies, notifies us that the United States is being split apart; that there are no longer any neutrals in America - everyone is either for or against Germany. The German element is finally getting its due because the greater majority of citizens has proclaimed itself hostile to the barbarians. The Excelsior says: "Anger reigns everywhere; it has caused acts of violence against Germans in New York, Chicago and Philadelphia" . $\frac{3}{-}$

An interesting observation may be noted about the make-up of the paper on May 12. The large head is entitled "The Exasperation of Americans". The three paragraphs which follow speak of Count Von Bernstorff's visit to Secretary Bryan, and his expression of sympathy

1. Millis, Walter, Road to War, pp. 70, 73, 147.
2. The Excelsior, May 10, 1915, p. 4, col. 3 .
3. Ibid., May 11, 1915, p. 9, col. 2.


(purely personal - not official) while the point of the article is found nearly at the end of the column, the head in very small type. Here we read that President Wilson, speaking before 4000 people at Fhiladelphia, has given a first indication of the attitude of the United States on the Lusitania affair. He is quoted as having said that the United States firmly desires to maintain peace, and will endeavor to convince Germany of the tragic injustice of her act. Baker analyses this speech made by the President:

The Philadelphia speech showed that the President had set himself against rushing the country into war, that he felt the limit of forbearance had not yet been reached, that he had decided Germany must have all the chance possible to make amends for what she had done and givo assurances against its repetition. I

On the next day comes news from Washington that President Wilson will present to Germany a note which was unanimously approved by the cabinet on the precoding day. The United States will insist upon obtaining an explanation of various incidents which have taken place since the establishment of the submarine war zone; principally the death of Mr. Thrasher, American citizen killed aboard the steamer Falaba; the bombing of the ship Cushing; the torpedoing of the Gulflight; and the destruction of the Lusitania. The Excelsior says :

1. Baker, Ray Stannard, op cit., p. 335 . 
Wilson wants the security of unarmed ships to be assured. The document interprets perfectly the deep indignation of the country toward these incidents, and asks in the name of international conventions the adherence of Germany to the established rules which govern naval warfare. 1

C. Hartley Grattan tells us these faots concerning the foregoing torpedoings:

(a) March 28, 1915, the Falaba (British Steamship) outward bound for Africa, was torpedoed and sunk in the Irish Sea. An American, Leon Thrasher, lost his life. Germany's explanations were that the Falaba endeavored to escape, that the first signal given was "Stop and abandon ship" - second signal, "Stop or will fire", and that between twenty and twenty-five minutes elapsed between first warning and firing of torpedo, and seven to ten minutes given after second signal. The ship carried no guns.

(b) On April 29, the American Steamship Cushing was attacked by a German sea plane. Four bombs were dropped - one struck the vessel. No lives were lost. The markings on the ship were inadequate. The German government offered compensation for her serious mistake. (c) The American ship Gulflight was torpedoed off the Scilly Islands liay 1. The vessel remained afloat and was towed to port. The captain died of heart failure - two of the crew drowned. The ship was in the vicinity of British Patrol Boats, and had been in communication with them. Germany assumed her an enemy vessel under convoy. Compensation was offered. $\underline{2}$

1. The Excelsior, May 13, 1915, p. 5, col. 2 .

2. Grattan, C. Hartley, op cit. pp. 287-288. 
It is important here to reflect upon the fact that the Gulflight was the only American ship torpedoed by the Germans during the entire period of American neutrality, in which any American lives were lost. 1

The fact that American citizens were killed on boats belonging to foreign governments did not seem to impress the world at that time. Today the attitude toward noutrality has undergone a vast metamorphosis. The United States now assumes no responsibility for citizens who imprudently risk their lives by traveling on vessels belonging to belligerent powers.

The same day, Nay 13, the Excelsior publishes Germany's communication to all neutral states. The German govermment states that it sincerely regrets the loss of the Lusitania but declines all responsibility; that English commercial vessels cannot be counted as simple merchant boats as they are armed; and that the Mauretania and the Lusitania were employed in the transport of war materials.

A dispatch fram New York also is published on May 13, which declares that several Wall Street bankers are convinced that Germany is trying to drag the United States into the war. An American financier who was in Turkey at the end of April is represented as having said that several German officers exclaimed to him:

1. Millis claims that with the sinking of the American ship Vigilancia on March 16, 1917, six American citizens were drowned. However, this was after diplomatic relations with Germany had already been severed. Millis, Walter, op. cit., p. 418 . 
We are going to force you to declare war; as long as European nations are being weakened by war, we certainly don't want America to have the oconomic and industrial advantages. 1

The next day the paper refers again to the German element in the United States. It publishes an article taken from the Staatszeitung (a German-American paper) which deals with a still debatable problem. The gist of the publjcation is that the large majority of GermanAmericans are believed to be with President Wilson to the end in all questions affecting national honor. The Excelsior adds, "Does that mean that German-Americans are counting on the President?" $\underline{2}$

Nothing else of importance appears in the Excelsior until May 19 , when we see the headline, "If Satisfaction Is Not Granted, America Will Declare Warn. The dispatch is sent from the United States to London via the Atlantic cable. It is to be noted that though the sum and substance of dispatches from America are printed fairly accurately by the Excelsior, the heads are naturally written by men on the Excelsior copy desk, so that a bit of free translation is likely to slip in. It is essential to realize that the allies because of the owmership and routing of the cables had at this time complete control and censorship over all information transmitted from America to England and the Continent, and vice-versa. America was so naive in her assumption that the suppression of military secrets was all the war censorships were interested in that "no one stressed the possible influence of the allied

1. The Excelsior, May 13, 1915, p. 5, col. 2 .

2. Ibid., Nay 14, 1915, p. 5, col. 1 . 
censorships upon the color of the news, all of which had to pass through these controls". 1 It is to be observed in reading this dispatch that it is much less vindictive and alarming than the head:

Americans hoping for the best are calmly prepared for the worst possible answer to the note sent Germany. The response will show whether it is the men of the state or the militarists who dominate at Berlin. If it is the latter, there will be war accordingly, at least a state of war which will render immense service to the allios.

It is not believed that troops will be sent to aid the allies; but it is probable that warships will serve as escorts to merchant ships. At least the example of America will have a favorable effect on other neutrals. While confidence in a pacific solution increases at Washington, officials there do not attach any special importance to a dispatch from Berlin saying that German governmental circles favor the idea of arbitration. 2

Some days later, we find an account published from an Amsterdam paper which says that Count Reventlow (an ex-navy officer and follower of Von Tirpitz) has printed a violent article against the United States, proclaiming that German submarine warfare against the commerce of Great Britain will be continued in as unsparing a way as possible. "America", he said, "can do as she wishes; we will not be intimidated either by her bluff or by her actions". $\underline{3}$

The German response to the American note was received in Washington May 31. The letter was simply a rebuttal of America's argument,

$$
\begin{aligned}
& \text { 1. Millis, Walter, op. cit. p. 62. } \\
& \text { 2. The Excelsior, May 19, 1915, p. 9, col. 1. } \\
& \text { 3. Ibid., May 30, 1915, p. 13, col. } 1 .
\end{aligned}
$$


and was certainly unsatisfactory in the sense that it did not directly meet the American contentions and demands. Houston speaks of it:

The German reply was unsatisfactory. It was insincere and cynical. It contained a statement to the effect that a great. liner had no right to sink so quickly merely from the effect of a torpedo, that it must have resulted from the explosion of ammunition, and that the lusitania had been armed. A final statement was reserved pending the receipt of further information from this government. 1

June 1, the Excelsior publishes the note, and takes great pains to show how unsatisfactory it has proved to the Americans. The text of the response is taken fram the semi-official Le Temps which obtained it through its correspondent at Geneva. To quote the Excelsior:

The response has augmented the tension rather than relieved it. It has been described by same newspapers as:

\section{New York Herald}

The note constitutes a position defiance although veiled by diplomatic language.

The World

It is worse then evasive; it lacks sincerity.

Philadelphia Public Ledger

The United States mustn't be lost in discussion when it is a question of the loss of American lives, people sacrificed brutally by a government which repudiates all human laws.

Boston Advertiser

It is insulting as well as astonishing.

1. Houston, David F. Eight Years With Wilson's Cabinet, Vol. I, page 136 . 
Here are the important points of the note itself:

The German government knows through information obtained by officials and by declarations of noutral pessengers that for a long time most of the principal ships of British commerce have been furnished with cannons, munitions and other armaments. It is a known fact that the Lusitania was armed.

For some time, the British government has advocated and has paid large sums for the destruction of submarines by merchant boats. Consequently, the German government does not consider merchant boats defenseless.

The company to whom the Iusitania belonged, was informed of the risk and danger the passengers were incurring by boarding the ship. The company sought to use the lives of American citizens as protection for its transportation of munitions. It violated all laws forbidding the embarkment of American citizens on ships carrying explosives. The company criminally caused the death of numerous passengers.

All information has proved that the fact that the boat sank so quickly was due to an explosion on board, provoked by a torpedo. Otherwise, according to human provisions, the passengers would have been saved.

The German government requests that the United States digest these facts and recall that the German government has favorably received the American proposition concerning the establishment of a modus vivendi on Anglo-Geman naval warfare, proving its goodwill toward America, while England has refuted the idea. 1

The Excelsior offers no comment on the facts stated in this note;

it neither questions their validity nor upholds them. Its ohief interest seems to center around the interpretation and attitude of the

United States toward the response itself, the facts being more or less disregarded. As for the question of ammunition carried by the Boat, Thomas A. Bailey corroborates the statement made by the German Foreign Office. 2 In discussing the first point of the German note (armaments

1. The Excelsior, June 1, 1915, p. 9, col. 1.

2. Bailey, Thomas A. "The Sinking of the Lusitania", American Historical Review, October, 1935, p.61. 
carried by the ship) Grattan says that it is still a question of dispute, but no one has denied the item in the New York Tribune Juno 19, 1913, stating that the Lusitania was being armed at Liverpool. I The consensus of opinion is now that the Lusitania was transporting munitions. Whether or not she was armed is still a subject of debate. But the important issue here is that the Excelsior declined to discuss it.

Three days later the Excelsior herds a column, "The Patience of the United States Has Its Limits", followed by an article saying that after a cabinet meeting held in Washington the previous day, President Wilson has decided to demand that Germany cease attacking unarmed merchant ships.

The United States will employ all honorable means to avoid hostilities but the patience of the American government has its limits. Even Mr. Bryan and Mr. Daniels, who at the beginning of the war were opposed to any drastic action, are convinced now that the United States must meet Germany face to face if she wishes to maintain the progress of civilization. -

On the following day, the headlines "Will the United States Participate in War", show once more that the wishful thinking, the longing for participation on the part of the United States has not subsided. The article below states that President Wilson's response to Von Bernstorff in their interview the day before must have been luoid enough, as the latter sent an urgent radiogram to Berlin saying that the President demanded the cessation of sub-

1. Grattan, C. Hartley, op. cit., pp. 291-292

2. The Excelsior, June $4,1 \overline{915}, \mathrm{p} .4, \mathrm{col} .3$. 
marine warfare, and that the whole country was behind him. Those at Washington who have studied the situation are of the opinion that the quickest way for the United States to assure peace is to place herself on the side of the allies, and do all in her power to holp them. "No one will be surprised if the United States decides this before long. 1

Thus this chapter closes logically with the Excelsior's publication of June 5th. We have seen how the Excelsior's attitude each day becomes more acute in its prejudice until finally in the last publication, it discards discretion and prints the headline, "Will the United States Participate in War?"

In spite of all that France, England and the Excelsior could do, President Wilson's diplomacy, ideals and obduration prevented the United States from armed intervention and combat at this time. But the "Lusitania Crisis" had left its mark. It obviously gave impetus to the preparedness movement; it served to alienate further the American citizens from the Central Fowers; it practically finished the German Propaganda Bureau, and finally it paved the way for the actual American declaration of war which followed two years later.

1. The Excelsior, June 5, 1915, p. 5, col. 2 . 
CHAPTER III

THE SUSSEX

MARCH 26 to MAY 12, 1916 
CHAPTER III

THE SUSSEX

MARCH 26 to MAY 12,1916

On March 24, 1916, the French cross-Channel steamer Sussex, unarmed and carrying over three hundred passengers, was torpedoed without warning. The whole front ond of the ship was blow off, but the after part continued to float and she managed to reach port. About eighty noncombatant passengers on board including several American citizens were wounded, some killed. No American lives were lost, however.

Once more a crisis had arisen, and "Diplomatically, the whole submarine problem was back again precisely where it had been on the morning after the Lusitania". 1

This period of the great war ranks utmost in importance with regard to the Excelsior's attitude. While the sinking of the Lusitania evokes from the Excelsior damning criticism of Germany, utmost praise for the United States and infinite hope for France, the attack against the Sussex spells only one word for this paper rupture - rupture of diplomatic relations between Germany and the United States. The publications which follow for at least a month after the torpedoing leave no doubt in the minds of the readers as to the daily's exact prediction of America's prospective action.

$$
\text { 1. Millis, Walter, op. cit., p. } 287 .
$$


The Excelsior is confident. Then in May the tide turns, and when all hope of rupture is forsaken, the paper makes a very graceful exit which may be noted in its article of May 12 th.

Sunday, March 26, two days after the attack on the Sussex, the Excelsior prints news of the disaster. An account of the circumstances of the torpedoing is given along with a word by word description contributed by a Mr. Chagneux, inspector of the Orleans Company. The number of victims is cited as eighty •

The following day, a picture of the Sussex is published. In the printing under the picture, one can see plainly the hope that an American has been killed:

By her latest acts of piracy, Germany tries to bring discredit on the United States. It was not known for certain at first whether there were any Americans on board the steamer Sussex, treacherously torpedoed by the Germans. The most exact information leaves no doubt; two of the fifteen or eighteen Americans on board were wounded, one seriously. Moreover, according to the declaration of Mr. Baldwin, an American passenger and citizen of Pennsylvania State, a Miss Hale who had displayed admi rable courage and nerve, lost her life. On board the Canadian steamer, Englishman, struck by the Germans last Friday, it is belieyed that there were equally as many Americans on board. 1

The article appearing March 28 expresses vividly the Excelsior's opinion with regard to America's attitude. It says that the American

1. The Excelsior, Miarch 27, 1916, p. 3, col. 2-3- 
patience is definitely at an end and that a newcrisis has assuredly burst forth between the United States and Germany. Even if the American government is not successful in obtaining proof that the Sussex and the Englishman were torpedoed, it is certain that it will not accept wi thout protest repeated attacks by German submarines. A dispatch from New York to the Daily Telegraph states:

The rupture of relations with Germany is dangerously near; up to the present, the United States had seomed to believe that Germany had respected her promise not to torpedo without warning ships carrying passengers, for it was not possible to prove that she had failed in her promise, Today, facts are too clear to permit longer hesitation. I

The following day, the daily informs us that Count Von Bernstorff, sensing the danger, has announced that Germany will disown the contrivers of the torpedoing. The ambassador attributes his intervention to the resignation of Adniral Von Tirpitz. The Excelsior says:

Ordinarily, Count Von Bernstorff is more clever; this time his manoeuvers have fired a long shot; Monday evening, the higher-ups of Washington and New York declared that their stand was taken with regard to Germany and its ambassador, and that the only way to stop the scandal was to dismiss Count Von Bernstorff. $\underline{2}$

Here the Excelsior is a bit premature. Mr. Lansing tells us in his War Memoirs of the intense struggle between himself and President Wilson in this issue. In his letter to the President, dated throe days after the Sussex was attacked, he wrote:

Proceeding on the assumption that the Sussex was torpedoed, the action which seems to me to be the most practi-

1. The Excelsior, Narch 28, 1916, p. 5, col. I.

2. Ibid., March 29, 1916, p. 5, col. 1. 
cable would be to demand the immediate recall of count Von Bernstorff and the severance of diplomatic relations with Germany. 1

Mr. Lansing states emphatically that the President did not for a moment entertain the idea of such drastic action.

The most recent study of the Wilsonian diplomacy seens to disagree on this point:

In the April crisis after the Sussex, Wilson is known to have authorized Secretary Lansing to prepare a note to Germany - severing diplomatic relations - an almost certain prelude to war. He held this note in abeyance for a week or so, then suddenly scrapped it and wrote another which left the door open for continued "neutrality".

The article of March 29 goes on to say that the citizens of the United States, and particularly the press, demand either explanations or rupture, for the question of submarine warfare must be compelled to conform with the firm stand taken by President Wilson and solemnly consecrated by Congress. At the very bottom of the column appears a dispatch sent from Washington:

From an authorized source they say that Germany persists in believing that it is a mine which struck the Sussex, but if it is established that the stearner was torpedoed, she will disown the commander as guilty of the violation of received orders, will punish him and offer reparation to the United States.

The next day, we learn that MIr. Lansing has charged the United States Ambassador at Berlin with opening an official inquest on the ship-wrecks of the Englishmen and the Sussex. The daily says that

1. Lansing, Robert, War Memoirs of Robert Lansing, p. 134

2. Arnett, Alex Mathews, Claude Kitchin and the Wilson War Policies, p. 187.

3. The Excelsior, March 29, 1916, p. 5, col. 1. 
while the government at Washington is not proceeding very rapidly, its habit is to study documents and situations carefully and slowly, and one would be wrong to conclude that this procedure signifies indifference to the facts themselves. American newspapers are declaring that these latest torpedoings have lowered forever the value of the German word. The Excelsior cites a quotation fram the World of New York:

The demands for information and the protests recentIy formulated by Washington have remained unanswered. While maritime terrorism strikes its limits, and while submarine atrocities are announced and celebrated in Germany, the goverment at Berlin continues to deny the responsibility and to cast it upon France and England. I

The column continues with the news that Chancellor Von BethmannHollweg has just convoked all the heads of the political parties in the Reichstag to discuss submarine warfare; that he will persist in placing the responsibility of the recent torpedoing on Admiral Von Tirpitz, because the latter, just before his official dismissal, had given the order to strike indiscriminately all merchant boats, and the submarines had already left their bases with these instructions when the Admiral retired. Here the Excelsior tries to score: - - But several days ago this departure was known. The submarines know very well how to keep themselves informed by means of the wireless telegraph when the government wishes it. Only yesterday they signaled the torpedoing of the Empress of Midland and the Eagle. The laborious excuse of the Chancellor, or of his friends involves just a deeper lie: $\underline{2}$

1. The Excelsior, Narch 30, 1916, p. 7, col. 1.

2. Ibid. 
We know it to be a fact that the German Chancellor hit upon this excuse to offset a rupture with America, but it is exceedingly clever of the Excelsior to recognize its invalidity and to print its exposure.

April 3 the Excelsior predicts that Mr. Von Bethmann-Hollweg will sway the Reichstag and succeed in his views of and plans for future submarine warfare. But the daily points out that neutrals must not expect any change whatsoever in the manner of operating the submarines; for they will torpedo, but they will deny having torpedoed. "In this way they will reconcile the Chancellor's point of view and the exigenoies of public opinion". 1

In the same column is found an open cablegram which Professor James Mark Baldwin addressed to the President of the United States.

A woman traveling where she had the right to be, with an American pessport, seriously wounded on the Sussex, hanging between life and death, demands that reparation be exacted for the attack against the life and liberty of Americans. (Reference was made to this Miss Hale in the Excelsior's article of March 26, 1916). Baldwin. 2

Three days later, just one year prior to the actual outbreak of American hostilities, the Excelsior prints these headlines, "Americans in Paris Demand Rupture with Germany". $\underline{3}$ The article states that the American Chamber of Commerce at Paris under the presidency of $M$. P. Peixotto has sent a cablegram to President Wilson, protesting against the continuation of diplomatic relations

1. The Excelsior, April 3, 1916, p. 5, col. 2.
2. Ibid.,
3. Ibid., 
with Germany. It is rather coincidental that Seymour in his Intimate Papers of Colonel House, tells of the fervid interview between the Colonel and President Wilson which took place on the same date and in which the former vehomently pleaded with the President to advocate armed intervention. 1 April 6, 1916, Colonel House virtually went to war, preceding the American nation by one year.

In the light of such agitation, it is not surprising that news comes from Washington April 11, announcing that from an authorized source it has been heard that diplomatic relations between the United States and Germany will be broken within the course of a weok's time. This is, of course, sweet music to French ears.

Again the author must make reference to the dispatches coming from the United States. The Excelsior does not have sufficient space to permit the printing of the entire dispatch, thus it is necessary to realize that the daily naturally selects and publishes certain salient points beneficial to its own particular mode of propaganda.

But the battle of the pens continues, and the American sword to the keen disappointment of the French remains sheathed, as is obvious on April 15, when information comes that the German response to the American demand for explanations has arrived in

1. Seymour, Charles, The Intimate Papers of Colonel House, pp. 230-233. 
Washington. The paper states that while the note has produced the worst possible impression on public opinion and is considered inconclusive, insincere and impertinent, Washington has not yet reached the point of rupture. It is believed that either the American govermment will send a new diplomatic note to Germany, which will be the last, or Mr. Wilson will inform Berlin that its explanations are unsatisfactory. The second mode of procedure will be advised by diplomatic personages who are convinced that the United States would only expose itself to ridicule in continuing this subterfuge.

The Excelsior proves that it attaches significance to straw votes taken in the United States when it publishes these headines, "Five Hundred Eminent Americans Express Their Sympathy for the Allies", followed by this article:

The American newspapers have published an address of sympathy for the allies bearing more than five hundred signatures of the most eminent people in the United States.

This address constitutes a remarkable profession of faith in the just cause of the allies, and declares that the future of civilization depends entirely upon the defeat of Germany.

Among the signatures figure the best known political names in the United States, senators, state governors, bishops, magistrates and presidents of universities. -

It is both easy and essential to grasp the feeling of confidenoe and assurance which the Excelsior displays, and which grows stronger every day.

Three days later, the daily announces that President Wilson has

1. The Excelsior, April 18, 1916, p. 7, col. 2. 
formulated and transmitted to Germany an ultimatum. One notices that the Excelsior adroitly employs the word "ultimatum".

The following day in the point of view column "ce que l'on dit à l'etranger", we find rather a strong article contributed by Pierre Mille. Mr. Mille is the renowned French novelist, essayist and journalist. He was once secretary to the Governor of Madagascar, and has been a member of various expeditions to Indo China, India, West Africa and the Congo. As is true of every newspaper, the editorials in the Excelsior are the highspots in an otherwise sensational and alarming daily. The columnists who are much more capable of visualizing and weighing the significance of facts are also much more subtle in their usage of propaganda. It may be noted how Mr. Mille transforms President Wilson's note into an ultimatum:

No, this time it is not a "note" which Mr. Wilson has sent to Germany. It is the clearest of ultimatums, including in the most solemn form the strongest and most verile commentary; one feels that the resolution of the President is immovable; that Germany must abandon her methods of submarine warfare or there will be a rupture of diplomatic relations. 1

Mr. Mille goes on to say that German opinion has been declared energetically in favor of submarine warfare as it is actually conducted, and Chancellor Von Bethmann-Hollweg, whose views differ, realizes that his decision will be to face either a crisis in the policy of the interior or a conflict with the United States. But

1. The Excelsior, April 22, 1916, p. 2, col. 2. 
since the United States has already primed conversation with other noutral states who are suffering fram the submarine campaign and an entente of all these states would certainly have the gravest consequences for Germany, it is not entirely beyond all foresight, he says, that she will renounce playing her inhuman game.

Mr. Mille, with little or no trouble, undoubtedly hits the nail on the head. Now in 1937, looking back over the four years of the great war, we realize that the German submarine was the only cause sufficient to provoke intervention by the United States. The author's contention is strenuously supported by Mr. Charles Seymour:

Except for the submarine, our quarrel would have been with the allies. Upon this Bernstorff, Grey and Lansing are agreed. In such a case it is entirely improbable that the diplomatic dispute would have dereloped into war. Sentimental consideratians, economic interests, sympathies of political leaders, all would have combined to produce a peaceful settlement of the quarrel. But all these factors, on the other hand, would have been powerless to drive us into war with Germany if it had not been for the Gorman submarine campaign. There lay the positive cause of American intervention. It is historically isolated, as one isolates a microbe. $\underline{1}$

On the same day, a cablegram from Washington tells us that Germany has asked the United States to give her two weeks for thought before her submarine policy can be declared.

Two days later, the paper carries an annex to the American

1. Seymour, Charles, American Neutrality 1914-1917, pp.170-171. 
note. This annex tells exactly how the Sussex was torpedoed. Testimony is given by many witnesses (passengers) who offer this information under oath of complete veracity.

Here is an example of how the daily employs pictures to sway the masses and to affect public opinion. The entire front page of the Excelsior is covered with photographs of President Wilson. The title reads, "Man of the Hour - President Wilson". The pictures show him: 1. delivering a speech, ("Humanity condemns your piratical procedures - abandon them or there will be a diplomatic rupture"), 2. with Mrs. Wilson, 3. bowing to the crowd, 4. as the professor of a University, 5. in his office, 6. leaving congress. The notation at the bottom is:

It's been scarcely several days since the President's note crossed the ocean and arrived at Wilhelmstrasse. Will it be rupture? Will Germany bend before the champion of the rights of humanity? While awaiting the response which will be made by the Emperor of the pirates, the newspapers of the entire world publish, under a thousand aspects, the portrait of the "President of the neutrals!" $\underline{I}$

During this period of anxious waiting, the Excelsior publishes at least one article a day, and continues to rehash the situation wondering and hoping.

On May 4, the German note was received in Washington. The decoded telegram promised not to sink any merchant vessel, even within the war zone, without warning and rescue of the passengers

1. The Excelsior, April 25, 1916, p. I. 
and crew, unless they attempted to escape or offer resistance. It added, however, a qualifying paragraph to the effect that if the United States could not succeed in altering the allied blockade, the German government would consider themselves faced by a new situation, for which they must reserve for themselves full freodom of decision. Seymour tells us that Colonel House in a letter to the President dated May 6, believed that since Germany had accepted the conditions laid down by the President, there was no excuse for a break; also that the paragraphs which raised the question of the British blockade should be ignored:

None of the papers have brought out the real concessions that the Germans have made. This I think should be done, and then I believe a rather curt statement should be made to the effect that we will deal with the other belligerents who violate intermational law as we see fit.

I do not see how we can break with Germany on this note. However, I would make it very clear to the German government through both Gerard and Bernstorff, that the least infraction would entail an immediate severance of diplomatic relations; and I would let the public know unofficially that this had been done. We will then have to wait and hope for the best. 1

In publishing the German note, Nay 6, the Excelsior is not willing to interpret the contents as charitably as the United States government:

The German Note Establishes - If One May Say So,

Her Record Of Hypocrisy. Impudence And Disdain.

After fifteen days, the note from Germany to the United States - who begged the Imperial Government to reply quickly - is known. One may read it below. One may

1. Seymour, Charles, Intimate Papers of Colonel House, p. 243. 
see in it re-written - the old German arguments; all that has happened is England's fault, and that of the neutrals (notably America) who did not oblige England to renounce the blockade. Germany is still the innocent one persecuted. Nevertheless, because of humanity and to please the United States, she is going to the extreme limit of possible concessions and giving her submarines new instructions - which are virtually the same as those with which the Sussex and so many other ships, charged as non-Combatants and neutrals, were sent to the bottorn of the ocean". 1

The note itself is omitted here; it is not important to us;

the Excelsior's comments are.

The following day, Pierre Mille airs his views:

The response of Germany to the United States can be sumed up in this way - Germany vill continue Germany will not continue. But Germany will renounce her manner of conducting submarine warfare only on the condition that the United States demand and obtain from Great Britain an immediate renunciation of her economic blockade.

It is perhaps not useless to remark that President Wilson is a jurist. As a jurist he cannot help but say that submarine warfare as practised by Germany radically violates international law, while the commercial blockade of an adversary has always been recognized as legitimate by this same international law. He can hold a discussion only on certain modifications of this blockade which hold to new rules of navigation.

That constitutes an inmense difference. It can't fail to gtrike President wilson - it is up to him to decide. $\underline{2}$

The same day, a very interesting picture strikes our eyes - a picture of the Lusitania. How they keep opening old sores! The Excelsior points out that through sheer coincidence, the date of Germany's response to the United States lacks two days of falling

1. The Excelsior, May 6, 1916, p. 3, col. 2-3.

2. Ibid., May $7,1916, \mathrm{p} .2, \mathrm{col} \cdot 2$. 
on the anniversary of one of the worst German crimes. The daily says that while the entire press branded the orime of the pirates, and wile newspapers across the Atlantic were unanimous in shouting their horror, Germany congratulated herself and produced post cards from the pictures of her victims. "This is a practise which our minds fail to comprehend". I

The entire paper seems to be keenly alive on this date. Page after page, and column after column speak of the sharp indignation provoked in London and America by this German response.

Two days later, the daily tells us that the American government has decided to send a short note to Berlin, informing the govermment that as long as the commanders of the German submarines obey the instructions given them, there will be no rupture.

The Excelsior's hopes are shattered still further when Washington sends word on May 11 that Germany has punished the Commander of the submarine which torpedoed the Sussex, and will offer a legitimate reparation.

The following day the paper publishes its crowning editorial of the period, signed by Mr. Pierre Mille. Mr. Mille's ingenuity is apparent in his attempt to disguise his disappointment. He proclaims that the American response to Gemany's note of liay 4 is the first great public humiliation that Germany has suffered since the beginning of the war. He argues that President Wilson's telegram dis-

1. The Excelsior, Way 7, 1916, p. 3, col. 2-3. 
plays moral superiority and assurance of the solidity of the juridical ground upon which the President walks; that Germany who believed herself so clever in the wording of her note has only set her own trap, since the United States has firmly declared that there is no relation between the allied blockade and the question of submarine warfare.

If Germany does not live up to the agreement prescribed in the American note, it is she who will have caused the rupture. And all the citizens of the United States are behind their President $1 \underline{1}$

Once again a crisis had been met and a catastrophe averted. The impossible had been accomplished, for Wilson had avoided war and yet maintained American prestige. How long the German pledge would be kept, no one knew. German public opinion was intensely bitter against America, but still feared to engage her in war. "Every night", wrote Ambassador Gerard", fifty million Germans cry themselves to sleep because all Mexico has not risen against us". $\underline{2}$

Thus closes this period. In reviewing these last pages, it is undoubtedly not difficult to grasp the feeling of confidence and assurance displayed by the Excelsior immediately following the torpedoing. Even after the situation has been settled pacifically

1. The Excelsior, May 12, 1916, p. 2, col. 2 .

2. Seymour, Charles, American Neutrality, 1914-1917, p. 42. 
through diplomatic measures, and the feat regarded as highly successful by the majority of Americans, the paper interprets the settlement in a highly one-sided manner, beneficial to itself and to France. 
CHAPTER IV

THE PRESIDENTIAL ELECTION AND

THE MEXICAN CONFLICT

JUNE 1 to JULY 1, 1916. 
CHAPTER IV

THE PRESIDENTIAL CAMPAIGN AND

THE MEXICAN CONFLICT

JUNE 1 to JULY 1,1916

As spring gave way to summer, the month of June approached with American opinion once more placated toward Germany and her submarine. The preparedness parade of May 13 had spent itself and accomplished its goal. President Wilson had made his speech at Philadelphia on May 27 in which he stated the attitude which "if it should ever be our privilege to suggest or initiate a movement for peace", he believed the United States should adopt. For the moment, the coming November election had forged to the front.

During the month of June, the Excelsior is concerned mostly with this presidential campaign, and later with the difficulties arising between Nexico and the United States. June 25, it publishes an amaing article by Jacques Bainville, revealing Germany's interest in Mexico, and America's slow but definite realization of the enemy's complicity in the affair. The period closes with the ultimatum sent by the United States to Mexico.

Very early in the campaign, the Excelsior's preference for Hughes is expressed in no uncertain terms. June 1, extracts from President Wilson's campaign platform are printed. Especially im- 
portant is the quotation in which Mr. Wilson speaks anticipatingly of a league of nations:

President Wils on answering critics who addressed him through the newspapers declared: "I would never consent that the United States enter into an alliance powerful enough to cause trouble in the country, but I would favor an alliance without responsibility which would free nations, for that is liberty".

June 7, the paper announces the republican platform, enumerating three points, 1. armaments, 2. military preparation for every citizen, and 3. suffrage for women. The Excelsior gives six to five odds on Roosevelt, and eight to five odds on Hughes. No amount of subterfuge can conceal the daily's ardent wish for a republican victory. One may observe this quotation:

If Roosevelt is elected president, he will make Eli Root Minister of Foreign Affairs. This will be a terrible blow to Americans who are pro-German, as they see in $\mathrm{N}$. Root the type of hostility declared against the central powers. $\frac{2}{2}$

Two days later, the Excelsior prints a picture of a parade on Fifth Avenue, New York, with a notation informing us that the movement to increase military effects and provide every means of defense for the nation is becoming more andmore popular. The slogan. now is "The United States stronger than ever". 3

The Excelsior announces the nomination of Mr. Hughes as republican candidate on June 12 .

1. The Excelsior, June 1, 1916, p. 5, col. 2.

2. Ibid., June 7, 1916, p. 4, col. 2 .

3. Ibid., June $9,1916, \mathrm{p} .3$. 
Rapidly the campaign is forgotten as on June 20, the Mexican affair comes to the foreground. At first only the facts are related, the official dispatches quoted. The column says that the situation in Mexico is more threatening than ever, and that the threat of Carranza, embodied in a letter addressed to the government at Washington, to attack the American expedition if it comes any farther south, is considered a gross insult.

Now that Mr. Wilson has been elected democratic candidate, he will act energetically without fear of being accused of profiting from the international situation. If Carranza again asks for the retreat of the American troops and accentuates his threat, it is probable that war will ensue. 1

The following day, we find published the American response to Carranza's note proclaiming that the government refuses to order the retreat of its troops as demanded and censures lexico for its discourteous letter. The response affirms in substance that the American goverment has decided to protect American citizens at any price, and not to withdraw the American troops until American grievances have been satisfied, and the lexican bands captured and punished.

During the three days which follow, the Excelsior fears that war is imminent, but on the 25 th comes an interpretation of facts embodied in an editorial written by Jacques Bainville. Mir. Bainville is the eminent French historian whose numerous histories of

1. The Excelsior, June 20, 1916, p. 5, col. 3 . 
France and biographies of outstanding French leaders are widely knowm, both on the continent and in America. He writes that Germany has created for America's benefit the "wasp's nest" in Wexico, and that it is interesting to observe that at Washington they immediately suspected the trap and have decided not to become ensnared in it. He goes on to say that the United States will not send her troops to Hexico to please the Germans, for Washington knows now whence the inspirations of Carranza came, and with what anxiety, the German Press was concerming itself with Mexican business. Nhis suspicion is a sign that the time has come when the German systern can no longer deceive anyone, nor take anyone unawares". 1

The same day, the paper tells us that a state of war exists between the two countries and that several South American states have offered to mediate. However, the United States has decided to wait twenty-four hours before taking any direct action.

Then on June 30, in large headlines the words, "Mexico Will Yield to Ultimatum of the United States" $\underline{2}$ appear. The publication says that the immediate rupture between the United States and Nexico has been avoided by Mexico's order to free the American soldiers taken prisoner at Carrizal.

1. The Excelsior, June 25, 1916, p. 4, col. 3.
2. Ibid., June 30, 1916, p. 5, col. 2 . 
Thus the Carranzists were humbled and began to cooperate in the pursuit of "bandits". The troopers captured at Carrizal were ultimately released, and by the early days of July the worst of the crisis was over. The orders to the National Guard, however, were not countermanded, and it continued to mobilize along the Rio Grande. Mr. Wilson, on the other hand, had played the strong hand again with a dangerously complete success. Fresh laurels of nationalist victory were upon his brow". 1 The hexican tension passed. While this period is relatively unimportant, it is more than possible to picture the anxiety of the Excelsior with regard to the Mexican conflict. Should America become engaged in war with the republic, what possible help could France expect from her? 
CHAPTER V

PRESIDENT WILSON'S OFFER OF MEDIATION

DECEMBER 23 to DECEMBER 31, 1916. 
CHAPTER V

PRESIDENT WILSON'S OFFER OF MEDIATION DECEMBER 23 to DECEMBER $31,1916$.

Tuesday, November 7, 1916, Woodrow Wilson was re-elected president of the United States. Immediately his thoughts turned toward the promulgation of peace. While the House-Grey Memorandum had proved futile, it had left the president committed to the idea of a league of nations and a permanent world peace system. He foresaw that the immediate end of the war in Europe was the sole visible means of escape for the people of the United States.

On September 25 and 26, Chancellor Von Bethmann-Hollweg definitely asked for a peace move through both Gerard and Bernstorff. I He waited for two and a half months with little success. Weary of America's dilatory measures, he dispatched a note December 12 to Washington which he requested the Government of the United States to transmit to the Entente Powers. The peace note which had been too long deferred was re-written by President Wils on and placed upon the cables December 18 .

On December 23, the Excelsior announces that President Wilson has asked the belligerents to make known their war aims and their

1. Millis, Walter, op. cit., p. 363 . 
conditions of peace. Jacques Bainville, in an editorial, wices his opinion and observes that a badly made peace, a peace premature and void of real guaranties would not shelter the world from the same agressions and same catastrophes whose weight is now felt.

By the same repeated catastrophes, the United States would find itself exposed again to the peril which threatens it today. Because of that, their interests are conjointly responsible with ours. And if their point of view differs sometimes, in some aspects, with that of the allies, it is perhaps because the United States does not yet have, in European business and affairs, the experience which has given us a half-century of German hegemony. 1

The following day in the column "ce que l'on dit à l'etranger", wo notice for the first time an expression of disappointment and displeasure in the Excelsior's attitude toward the United States. This feeling prevails throughout the entire period. We realize that the paper senses that all is not well for the allies, and that Germany is liable to derive the benefits from President Wilson's move. Pierre Mille conments that the United States seems to ignore the fact that when Germany declared this war, she didn't speak of the rights of the little states and of a "league of nations to assure peace and justices throughout the world", because then she thought to win this war. It is only since she has realized success to be impossible that she uses this language. He continues to say that the allies have already made their declaration of conditions by which the war could be ended; they 
demand of the Central Powers "restitutions, reparations and guaranties". And one more thing which Mr. Wilson seems to have neglected, Mr. Mille says is the question of "war guilt":

It is imposible that in the eyes of justice, right and the conscience of the Universe, the aggressor be treated as the aggressed, the robber as the robbed, the assassin as the victim. It is common sense which forbids it; it is equity; it is the most elementary honesty. If President Wilson deigns to give proper place to this question the allies may listen to him. Otherwise, it is useless for him to make the slightest gesture to them to lend him their ears. $\frac{1}{-}$

The following day, the daily prints an article taken from the Frankfort Gazette - favored organ of Chancellor Von BethmannHollweg. The column declares that it is very agreeable to the Germans that President Wilson's step followed their offer of peace because in that way, the independence of Germany and the spontaneity of her movement are shaded from suspicion. Also that the initiative, so praiseworthy of President Wilson, will in no way derange the plans of Germany, and will not make her deviate from the road she has chosen. Jacques Bainville comments:

The hypocrisy of this official language jumps to the eyes immediately. It is too clear that Germany dissimulates the satisfaction wich the American note has caused. She assumes grand airs in declaring that she has need of no one. However, she shows herself ready to seize the occasion to use the circumstances to her advantage and to profit from the manoeuver. 2

1. The Excelsior, December 24, 1916, p. 2, col. 2 .

2. Ibid., December 25, 1916, p. 3, col. 3 . 
David F. Houston, in discussing December 15 with Wilson and McAdoo the wisdom of sending the American note to the allies, was apt in his prediction of the reaction which followed. He was reluctant in transmitting it so soon after the German note, and feared that it might be resented by the allies and regarded as an act of friendship toward Germany. 1 Every article published by the Excelsior during this period bears out the accuracy of $\mathrm{Mr}$. Houston's prophesy.

On December 27, a dispatch from Washington informs us that President Wilson is greatly moved by the reception which his offer has gained from the allies. The article states specifically that $\mathrm{Mr}$. Wilson is extremely disappointed in the interpretation placed by the French Press upon his offer of mediation.

On the next day, the response of Germany and Austria to the President's offer is printed. Jacques Bainville again evaluates it and interprets it to mean that Germany is trying to accredit the idea, which Mr. Wilson suggested to the allies, to the procedure offered by lir. Von Bethmann-Hollweg; but he says in reality Germany only refuses to answer the question put to her. Mr. Wilson proposed dialogue - Germany continues her monologue, and tries to impose her point of view in favor of 'quid pro quo' ". $\underline{2}$ The same day, an article sent from Washington to the Daily

1. Houston, David F., op. cit., p. 219.

2. The Excelsior, December 28, 1916, p. 3, col. 3 . 
Mail in London is published. The article says that Washington is disappointed in the German response because it does not contain peace conditions; and that the desire of the American government to be represented at any conference for future peace is only a right. This last phrase is extremely important, as it is obvious that the French do not want this either.

Also in the same edition comes a telegram fram Berlin saying that the Berlin Press approves unanimously of the response of the Central Powers to President Wilson's note, and that it does not believe that the efforts of the President have much chance of being realized.

December 30 , the response of the allies with regard to the question of peace is published. The following day Jacques Bainville writes:

There are but few comments to add to the note which was sent yesterday to the United States. Ambassador at Paris and which is the response given by the allies to the pretended offers of peace which Mr. Von BethmennHollweg lanced December 12. This historical document is sufficiently explicit in itself. It translates with vigor, the sentiments, ideas and good will of the peoples attacked by Germany and Austria, and of those who are leagued against the Central Powers, to resist the abuse of force and to re-establish the equilibrium of Europe and the liberty of the world. It denounces the lie on which the enemy's proposition rests, and revpals the German proposition to be only a war manoeuver. -

1. The Excelsior, Decomber 31, 1916, p. 3, col. 2 . 
Thus the German "peace offensive" and Wilson's offer of mediation proved failures. Still the President couldn't realize that the case was hopeless. He didn't know that on the very day when his note was filling all the newspapers, General Ludendorff was writing to Zirmermann, the new Foreign Secretary, convincing him that since Lloyd George had spurned the German offer by his declaration in the House of Commons, the U-boat campaign should be inaugurated in full force.

The last day of the year 1916 closes this chapter. As has been stated before, the Excelsior's publications display a certain amount of rexation and pique toward President Wilson and his altruistic (and idealistic) proposal. But in the paper's article of December 31, Jacques Bainville conveys the impression of undefeated optimism. 
CHAPTER VI

THE EVE OF AMERICAN INTERVENTI ON

FEBRUARY 15 to APRIL 7, 1917 
CHAPTER VI

THE EVE OF AMERICAN INTERVENT ION

FEBRUARY 15 to APRIL 7,1917

The month and a half before America actually declares war the Excelsior becomes more and more intense in its attack on Germany, and more solicitous in its appeal to the United States to save the world and civilization. Propaganda is not discarded, but its veil is more or less lifted, and the Excelsior no longer shadows its words with sublety or hesitates to voice its true opinions. Each day its six or eight pages are devoted almost entirely to news of the United States, so much in fact that the paper, were it not written in a foreign language, could easily be mistaken for a New York Daily.

In view of the fact that there is so much repetition and so much material of really minor value, many of the publications will be omitted, giving way to those of intrinsic importance which best express the Excelsior, its attitude and outlook.

February 15, in discussing the Yarrowdale affair, mainly whether or not Germany will release the crew, the Excelsior says:

Chaque jour entraine l'Amerique vers la guerre, and:

The affair certainly is of a nature grave enough

to force America into conflict with Germany.

The following day, an article published in BERLINER TAGEBLATT

1. The Excelsior, February 15, 1917, p. 2, col. 1. 
(a Berlin newspaper) is printed. It deals with the sea voyage of the Orldans and Rochester:

We leave sensations of a three ring circus to the Americans. Only one thing interests us. Is she seoking a cause for war in sending her ships to Bordeaux? Our answer is not yet forthooming. But the responsibility will fall not on us, but on her and her president.

Whoever takes a death course in the ocean must bear the consequences. Perhaps the Americans think it is a sport and not a question of life or death. This course taken by the Orleans and Rochester proves they have not yet discovered the difference. 1

The Excelsior reluctantly admits the next day that Germany has freed the Yarrowdale crew:

Germany wishes relations with the United States to remain as friendly as possible in spite of broken diplomatic relations. Since Germany makes no concessions with regard to her prohibited zones the war is at the mercy of the torpedo. Ameriga knows that and is ready to toke active measures. 2

Throughout the six wreks a great deal of space is given to news of war preparations in the United States. The Excelsior plays up this point heavily. Each day tells us of new cruisers being added to the fleet, strategic points in the country being armed, Wilson's demanding from Congress an extension of powers, submarines built for Chile being kept for the navy.

February 20 the paper uses a word which has since become the backbone of American thought - "honor". In discussing mili- 
tary preparations and precautions, it states: "It is noticed that public enthusiasm for defense of the American honor is predominant ${ }^{n}$ The same day Washington telegraphs news that plans are being made to arm the merchant boats and that Germany is endeavoring to keep peace with the United States, so much in fact that she has permitted some American boats to go through the forbidden zones. The Excelsior contradicts this fact, "The confirmation that Germany is letting American ships through does not correspond with any other nows we have received". $\underline{2}$

February 23 word is published that the Rochester and the Orleans are preparing to enter the forbidden war zone. Germany says if they pass in front of a torpedo lance zone, "leur sort est clair".

In spite of the anxiety for these boats displayed by America, Germany and the Excelsior, they both reach Bordeaux in perfect safety

The next day the Excelsior says that the appalling economic situation in the Inited States is causing a revolt among the eastern states, and that this internal strife is sufficient to provoke war. February 27 the Laconia is torpedoed without warning. Two American women are reported killed.

Two days later, the Excelsior prints;

All dispatches received from Washington and New York confirm the opinion that this new German crime has raised in the United States a very deep and live indignation. The American goverrment has resolved to act and without delay. Dramatic events are expected to take place within the next twenty-four hours. $\underline{3}$

1. The Excelsior, February 20, 1917, p. 2, col. 1.

2. Ibid., p. 2, col. 2 .

3. Ibid., March 1, 1917, p. 2, col. 4. 
On this very day, the newspapers in America were shouting the headlines, "Germany Seeks An Alliance Against Us; Asks Japan And Mexico to Join Her; Full Text of Proposals Made Public". The Zimmermann telegram had come to light! The headlines, it is to be observed, are not always precisely accurate. Germany had not actually sought an alliance; the text of the telegran expressly instructed the Minister in Mexico to initiate the move only in the event that the United States should declare war, which the German government would itself endeavor to prevent. Mr. Millis says, "It was not a proposal for an aggression against the United States, but merely a conventional, though rather blundering, diplomatic preparation against a probable American attack upon Germany" .

The nows of this so called fathomless treachery of the Germans is recorded by the Excelsior March 2. Only the facts contained in the telegram are published. Then on the following day the daily makes quite an issue of Japan's scornful refusal of alliance. The Excelsior is careful to print the entire Japanese official communique. Wile emphasizing the fact that Japan is in complete accord with the United States, the paper adds that Japan, herself, views this proposal with scom. As for liexico, the daily says that she never intends to come out of her neutrality, for the reorganization of the country is too serious a task to permit entanglement in the great conflict.

1. Millis, Walter, op. cit., p. 407 . 
Three days later, the Excelsior tells of the filibuster led by twelve men in Congress, which prevents the arming of merchant boats from taking place. Concerning this issue, the Excelsior expresses the wish that President Wilson will demand a new rule concerning the voting minority of the govermment.

On the same day, the paper voices another opinion:

The Germans have decided to fight the whole world with the submarine. The Americans can, if they wish, create a new situation on the sea by stopping the construction of large battle-ships, and building 2000 patrol boats of uniform size which can be assembled and constructed as rapidly as the Ford Motor Cars. 1

In spite of congressional opposition, President Wilson gives the order Narch 11 to arm merchant boats in order to assure them defense in case of a German attack. The Excelsior says, "The first torpedo means war. If an attack on Germany's part takes place, a declaration of war will follow immediately. $\underline{2}$

Two days later, the daily informs us that war has not yet been declared between the United States and Germany, but it is certain that it soon will be. Since the government at Washington has authorized armed merchant ships to open fire on submarines whose intentions are presumed hostile, there seems to be no way of escaping it.

March 14, we see another article by Jacques Bainville. He stresses the fact that since Washington's orders to armed merchant boats are to fire at the sight of a periscope, there are but three words to characterize the situation, "c'est la guerre"; also that while Ger-

1. The Excelsior, March 6, 1917, p. 3, col. 5.

2. Ibid., March 12, 1917, p. 2, col. 1. 
many still wishes to avoid a declared state of war, she will succeed only at the price of humiliation.

The following day, $\mathrm{Mr}$. Bainville tells us of the sinking of the Algonquin:

Mr. Zimmerman had said, and the entire German press had repeated after him -- "We will not retreat an inch". The submarines have executed to the letter these instructions. An American ship, the first since the rupture of diplomatic relations, has been torpedoed without warning. Germany wished this, and is cognizant of the fact that she has committed "Casus belli".

Several days ago, Emperor William, receiving an ambassador, dared to say he regretted to admit that the Orleans and Rochester had not been sunk, because it was necessary to prove that Germany was resolved to break the resistance of England.

The German submarines missed these two boats, but the Algonquin did not escape them. By the very logic of her system, Germany plays double on nothing with her submarine blockade. She will notice that America is a solid enough player to accept this kind of "Banco".

Word comes four days later that three American ships have been torpedoed, the Illinois, the City-of-Memphis, and the Vigilancia. In two of these sinkings there was no loss of life, but fifteen men drowned with the Vigilancia.

March 21 Bainville writes:

The situation in the United States has become considerably more important and serious since the triple torpedoing. War appears today no longer an inevitable consequence of the submarine blockade, but now the only possible issue. America is approaching war "a Grands pas". 2

The same day, the Excelsior tells us that President Wilson is

1. The Excelsior, March 15, 1917, p. 2. col. 1.

2. Ibid., March 21, 1917, p. 2, col. 4. 
examining amendments which will permit him to advance the date of the special session of Congress fixed at April 16, and that all hope of seeing the situation settled pacifically has vanished. The next day, we read that the meeting of Congress is set for April 2. In view of imminent war with Germany, representatives of the large copper mines and industries have offered to deliver to the government $50,000,000$ pounds of copper at half the market price. Last depositions of war are published on March 23. Wilson has called for 500,000 volunteers. Industrial mobilization is being actively pursued. The United States has advanced $5,000,000,000$ francs to the allies. American railroads are preparing for mobilization.

March 24, comes news that the Healdton, Standard Oil ship, has been torpedoed. Twenty men are reported to have perished.

The next day, the Wolff Agency in America telegraphs Berlin that there is no longer any hope of maintaining peace. At a meeting in Madison Square Gardens the preceding day, 15,000 men clamored for war. The only question left for the United States to decide is the nature of help she will bring the allies, and in what way she can most efficiently assure them the defeat of Germany •

The rest is history. April 2, President Wilson addressed Congress and pleaded for war. April 4, the Senate passed the resolu- 
tion with six dissenting votes. April 6, the House passed it with fifty dissenting votes. The same day, war was officially declared. There is no need of going on with Excelsior's daily publications. By March 25, we can see and understand every phase of the paper's attitude. The articles that follow only continue to spur on the United States, and to glory, between the lines, in every German outrage. From the first of April until the seventh, the paper is transformed practically into a tabloid with pictures of the United States, and three-inch headlines smeared from cover to cover. The Excelsior has fought a hard battle, but it has attained success. 
CONCLUSI ON 


\section{CONCLUSION}

In this treatise, it is hoped that no shadow of doubt remains with regard to the attitude of France toward the United States, as expressed by the Excelsior newspaper. In the six periods covered, the connotation in each publication is easily grasped.

In the early period of American noutrality, the daily concerns itself for the most part with the reaction of the United States toward the declaration of war. Unaware of the fact that America, because of the unexcelled system of allied propaganda, is already giving passionate sympathy to the allied cause, the paper continually emphasizes the reception that German vandalism and atrocity are gaining in the new world. It attaches significance to the rebukes suffered by foreign diplomats at the hands of President Wilson, and places emphasis on the opinion of the American Army with regard to the duration and issue of the European conflict.

When the Lusitania is sunk, the Excelsior pulls every available string to draw the United States into the melting pot. Germany has caused the death of American citizens, and Germany must pay. The fact that these American citizens have selfishly incriminated the United States by traveling on a vessel owned and operated by a belligerent power which was carrying undeclared and 
illegal explosives, means nothing to the daily. The fact that the allied blockade is bringing death and starvation to thousands of Germans daily is not even mentioned. The German submarine has massacred 124 Americans and the United States must retaliate by joining the allied forces in armed combat.

The Excelsior fails in the "Lusitania Crisis", but in Niarch 1916 comes the fate of the Sussex which undoubtedly spells rupture. The stage is set, the actors are in the wings awaiting their cues but the curtain does not go up! Suddenly across the Atlantic comes word that Germany has yielded to the American ultimatum and the United States has accepted the German pledge. Once again, American diplomacy triumphs over French sentiment.

When the presidential election in America draws near, the Excelsior readily expresses its preference for a republican victory. The opposition of Woodrow Wilson toward armed participation has proved too strong for France, but with Mr. Hughes as president the policy of the Great Neutral might change. The daily is quick to see through the German agitation in Mexico and quicker still to publish its exposure.

With war between the United States and liexico safely averted, the Excelsior centers its attention upon President Wilson's offer of mediation in December. For the first time a note of displeasure is sensed in the daily's publications. Although the President's note actually receives scant attention in France, the Excelsior vehemently expresses its disapproval. Wilson, in following too close upon the 
heels of Bethmann-Hollweg's peace proposal, definitely has chosen the unpropitious moment, and the newspaper very graciously informs him of it.

The German submarine campaign is renewed in full force on February 1, 1917. The only possible course of action open to the United States is obvious to the Excelsior. No amount of strategy or diplomacy can color the situation - the United States will declare war. It is interesting, nevertheless, to observe the methods used by the daily to accelerate the outcome of events. Propaganda flamboyant and undisguised swings into action and slowly opens the gates for the American soldiers.

Had there really been a question in the minds of the publisher and editor-in-chief with regard to which cause the American Nation would uphold, the make-up of the daily might have been totally different; but as it stands, the Excelsior was confident the United States would act according to its own line of reasoning, judiciously. 
BI BII OGRAPHY 


\section{BIBLI OGRAPHY}

BOOKS

Arnett, Alex Nathews, Claude Kitchin and The Wilson War Policies, Boston, Little, Brown \& Co., 1937.

Baker, Ray Stannard, Woodrow Wilson - Life and Letters, New York, Doubleday \& Doran, 1935.

Carroll, Malcolm E. French Public Opinion And Foreign Affairs $1870-1914$

New York \& London, Century Co., 1931.

Grattan, C. Hartley, Why We Fought,

New York, The Vanguard Press, 1929.

Hayes, C. J.H. France A Nation Of Patriots,

New York, Columbia University Press, 1930.

Houston, David F. Eight Years With Wilson's Cabinet,

New York, Doubleday, Page \& Co., 1926.

Lansing, Robert, War Hemoirs of Robert Lansing,

Indianapolis \& New York, Bobbs-Merrill Co., 1935.

Millis, Walter, Road To War,

New York \& Boston, Mifflin Co., 1935.

Ponsonby, Arthur, Falsehood In War Time,

New York, Dutton, 1929.

Seymour, Charles, American Diplomacy During the World War,

Baltimore, The Johns Hopkins Press, 1934. 


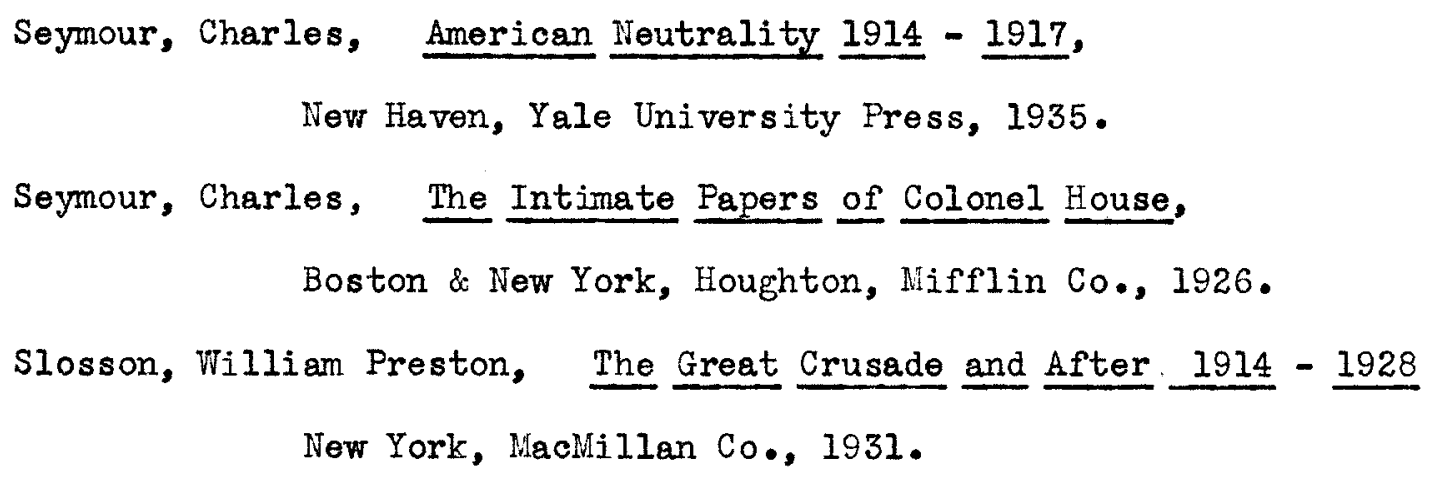

\section{NEWSPAPERS}

The Courier-Journal, Louisville, Ky • September, 1914; Nay, 1915; Narch, 1916.

The Excelsior, Paris, France, 1914-1917.

\section{PERIODICALS}

Bailey, Thomas A., "The Sinking of the Lusitania", American Historical Review, November, 1935.

Editor \&: Publisher, International Year Book For 1936, New York, January 25, 1936.

Europa, Encyclopedia of Europa,

London, November, 1935.

Lutz, R. H. "Studies of World War Propaganda", Journal of Modern History, December, 1933. 